\title{
Migration Discourse in Croatian News Media
}

\author{
Katja Dobrić Basaneže* \\ Paulina Ostojić**
}

\section{SUMMARY}

This paper investigates migration discourse in Croatian news media by combining corpus linguistics and critical discourse analysis approach. It first focuses on the phraseological and grammatical context of the terms migrant, imigrant, izbjeglica and azilant, whereupon it investigates the background of such linguistic behaviour. The latter is examined by means of critical discourse analysis, hence, by taking into account the non-linguistic context. This includes the analysis of historical, cultural and political context or sometimes even the relevant case law and standards of protection guaranteed in international humanitarian and human rights law. Results of the study suggest that discrimination does not occur only in the most obvious acts of inhuman treatment, such as pushbacks, but also in the language the media use when reporting on migration process.

Keywords: corpus linguistics, critical discourse analysis, discrimination, media, migration crisis

\section{Introduction}

Human migration is as old as humanity (Tzevelekos and Kastelli Proukaki, 2017: 440). In ancient times people moved from one place to another mostly in search for food. Nowadays these reasons range from better employment possibilities to persecution. In 2015 Europe witnessed a significant inflow of migrants, who were forced

\footnotetext{
* Katja Dobrić Basaneže, Senior Lecturer, Department of Foreign Languages, Faculty of Law, University of Rijeka, Hahlić 6, 51000 Rijeka, e-mail address: kdobric@pravri.hr ** Paulina Ostojić, mag. iur., trainee attorney, Law office Sandra Ivić, Stara vrata 8, 51000 Rijeka, e-mail address: ostojic.paulina@gmail.com
} 
to flee their countries of origin, especially owed to the aftermath of Arab Spring of 2011 and the civil war in Syria. Needless to say, Europe was facing a serious migration crisis, with the inflow of foreign migration reaching 5 million in $2015^{1}$. Croatia was at first the country through which migrants only passed through to reach their final destinations, usually in Austria or Germany. The strategy of the Croatian government was therefore to "permit the entry of refugees, organize their transit towards other European countries and control their movements through Croatia" (Čapo, 2015: 394). The system did function well up until Hungary decided to stop accepting migrants and Croatia had to reroute them to Slovenia (ibid.: 400), who in turn did not have the capacity to accept such large numbers of people. Consequently, Croatia was forced to slow transit, although the inflow of migrants at the border did not diminish. This made migrants force entry into Croatia and made the country, once "with a big heart", a place of degrading and inhuman treatment. Naturally, the topic was widely covered in the media, which at times created an "unbalanced image of the management of the refugee transit" (Čapo, 2015: 402). Croatian media were not the only ones who did not "mirror realities" (Fairclough 1995: 103), given the fact that research into narratives of migration crisis in the newspapers of eight European countries (Czech Republic, France, Germany, Greece, Hungary, Ireland, Serbia, UK) also reveals similar trends (Georgieu and Zaborowski, 2017). Even Oxford's language monitoring corpus indicates that the usage of the word refugee increased by about $110 \%$ and that of the word migrant by about $158 \%$ in 2015 , as compared with the same period in 2014 . $^{3}$ Interestingly, the corpus suggests that mostly the attention was on the distinction in meaning between the two terms. Corpora compiled of news articles, however, imply that news outlets very often use the terms interchangeably, contrary to the definitions offered in international instruments. This paper thus sets out from a monolingual corpus of Croatian news articles published in various news outlets. It focuses on the usage of the terms migrant (migrant), immigrant (immigrant), izbjeglica (refugee) and azilant (asylum seeker) as well as their wider context to detect their positive or negative prosodies. Since media migration discourse has thus far been mostly examined within the context of English-speaking countries, this paper attempts to fill these research gaps by focusing on media discourse of a language of lesser diffusion. The paper adopts a corpus linguistics approach but it combines it with critical discourse analysis in order to account for the non-linguistic context of the investigated keywords (e.g. reasons for their positive or negative prosodies).

\section{Theoretical background}

Refugees, asylum seekers, immigrants, and migrants have attracted considerable coverage in the media in the last fifty years (Greenslade 2005). Different studies 
argue that the discourse evolving around these terms is mostly negative (Van Dijk, 2005), even though fair coverage in European media is shaped by a number of relevant treaties (e.g. the European Convention on Human Rights and the Framework Convention for the Protection of National Minorities 15 (FCNM)), which "provide legislative tools for the members of the organisation to take effective action against hate speech and discrimination, while protecting freedom of expression for the media and for minorities and also for promoting and protecting independent journalism and access to media production and consumption for all" (Georgieu and Zaborowski, 2017: 15). Nevertheless, most studies focusing on media migration discourse reveal the opposite trend, pointing to the evolvement of hostile discourse around this vulnerable group and leaving migrants, immigrants, asylum seekers and refugees voiceless in those narratives. The majority of studies investigating migration discourse in the media adopt a critical discourse analysis (henceforth: CDA) approach, which allows us to carry out a close analysis of texts to reveal "transparent structural relationships of dominance, discrimination, power and control, as manifested in language" (Baker et al., 2008: 280). The flaw of CDA, however, is that it is time consuming and that it can only analyze a small number of texts. Furthermore, CDA studies have also been criticized for its arbitrariness in the selection of texts, which can in turn make texts less representative (Gabrielatos and Baker, 2008: 6). Most recently, migration discourse has been studied combining a corpus linguistics (henceforth: $\mathrm{CL}$ ), which allows us to electronically process large collections of texts, and a critical discourse analysis stance (Gabrielatos and Baker 2008, Baker et al. 2008, O'Regan and Riordan 2018). It seems to be a method that yields most reliable results, for it combines frequency of distribution of the relevant patterns with careful examination of the linguistic and non-linguistic context of those patterns, which very often offer insight not only into what was said, but also into why something remained unsaid (Fairclough, 1995: 107). All these studies, however, are devoted to the migration discourse of English-speaking countries, leaving the field of smaller cultures and languages of lesser diffusion largely underexamined. Migration discourse in Croatian news media, for instance, was investigated to some extent but either only from the ethnographic perspective (Čapo 2015) or from the perspective of content analysis on hand of a relatively small corpus (Razum 2019). This study thus conducts a corpus-based analysis on hand of a corpus of Croatian news articles consisting of 327,924 words from various Croatian news outlets. The linguistic analysis includes the analysis of collocations of the key migration terms (migrant, imigrant, izbjeglica i azilant). Since these terms are in most studies focusing on migration discourse in the UK press collectively referred to as RASIM (Gabrielatos and Baker 2008, Baket et al. 2008) (Refugee, Asylum Seeker, Immigrant, Migrant), the same decision was made in this study as well. The CDA part of research, on the other hand, focuses on the non-linguistic context of the extracted 
key words and includes the examination of both the type of news outlet in which the positive or negative attitude is created as well as the examination of political, historical, cultural or legal context behind it.

\section{Croatian press}

Since this study is corpus-based, the sources used for designing the corpus include electronic news outlets. While it is sometimes considered that electronic newspapers are the ones available in both electronic and paper form, some narrower definitions of the term suggest that electronic newspapers are newspapers available exclusively in electronic form (Lancaster, 1995: 520). For the purpose of this paper, however, we take into account the wider meaning of the term, according to which electronic newspapers can (but do not need to be) available in both electronic and printed form. Other criteria include frequency of publication, coverage, political stance and style (Gabrielatos and Baker, 2008: 8). These criteria were thus taken into account in the classification of Croatian press as well. By way of illustration, while jutarnji.hr was classified as national, left and daily broadsheet, index.hr was classified as national, left and daily tabloid. The difference between the two, however, is that jutarnji.hr also publishes articles in printed form, while the latter does not.

It is a well-known fact that the press can influence the views of the public (ibid.). Furthermore, since the discourse evolving around the key terms of migration has been mostly negative (Pugh 2004, Rasinger 2010), we hypothesize that the terms migrant, immigrant, refugee and asylum seeker will in Croatian press also mostly carry negative connotations. The media inevitably create perception about migration, especially if we take into account that at the beginning of migration crisis in 2015 most migration in Croatia was "dislocated", hence, reception centers were situated far from the eyes of local inhabitants and the public was informed thereabout through the media. We also hypothesize that in some newspapers the discourse might be "less negative" and for this reason it is important to take into account the above categorization of newspapers.

\section{Corpus}

The corpus compiled for the purpose of this study consists of three subcorpora. The first subcorpus contains articles from the time period before the migration crisis (MigCorp 2002-2014) and consists of 101,416 words. The time frame of the second subcorpus, on the other hand, is the very beginning of migration crisis in Europe (MigCorp 2015-2016) and this subcorpus consists of 101,626 words. Finally, the third subcorpus contains articles published from 2017 to 2019 (MigCorp 2017- 
2019) and consists of 124,882 words. We deliberately divided our corpus into three subcorpora to see whether the discourse is any different in the time period before and during the migration crisis. In addition, we were also interested whether there are some shared collocates between the three subcorpora and whether there are some that occur only during one period. Since all three subcorpora include articles from broadsheets and tabloids, both national and regional, we can claim that they are balanced and representative.

\section{Methodology}

In order to investigate our corpus, we used Sketch Engine software (Kilagriff et al. 2014), primarily its tools Keywords, Word Sketch and Concordance. We first extracted a list of keywords from each subcorpus. The keywords were tested against hrwac 2.2. (Ljubešić and Klubička 2014), which is currently the only reference corpus available for Croatian language in Sketch Engine. The terms migrant, imigrant, azilant and izbjeglica were in each subcorpus among the top five keywords. The next step included running word sketches ${ }^{4}$ of those terms in each subcorpus to investigate their collocational behavior (see Figure 1).

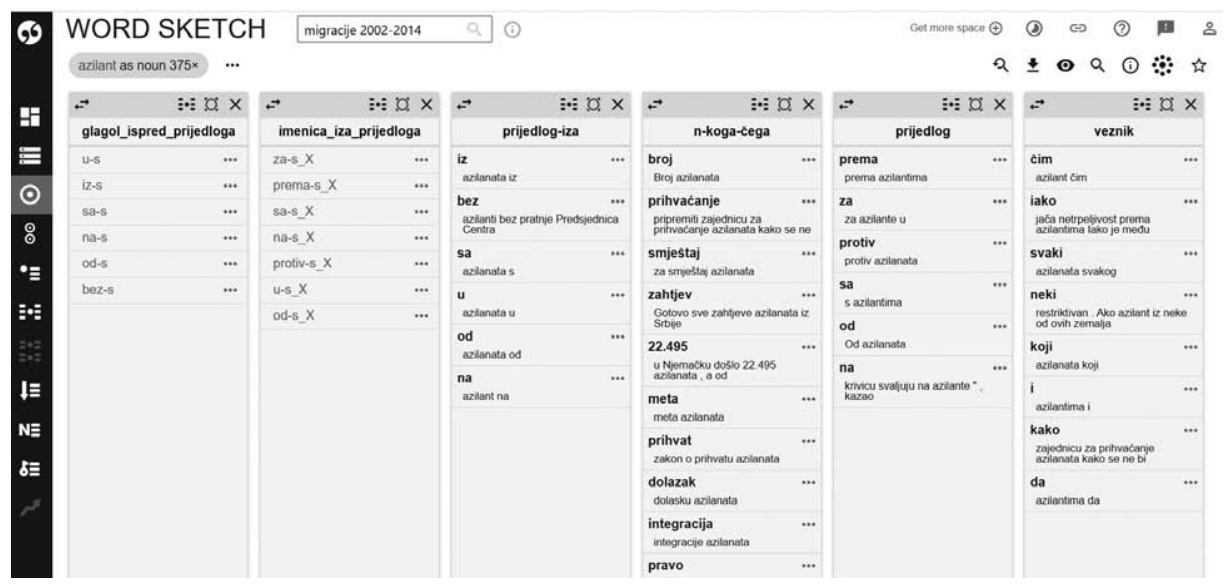

Figure 1. Word sketch of the term azilant in MigCorp 2002-2014

Slika 1. Prikaz termina azilant u alatu Word Sketch u MigCorpu 2002-2014

Since the program sometimes lists collocates that do not necessarily need to classify as such, we also ran concordances ${ }^{5}$ for each collocate (see Figure 2) to convince ourselves into their collocational status as well as to analyze the wider context of the collocate. The latter proved especially useful for our study, since not all concord- 
Medij. istraž. (god. 27, br. 1) 2021. (5-27)
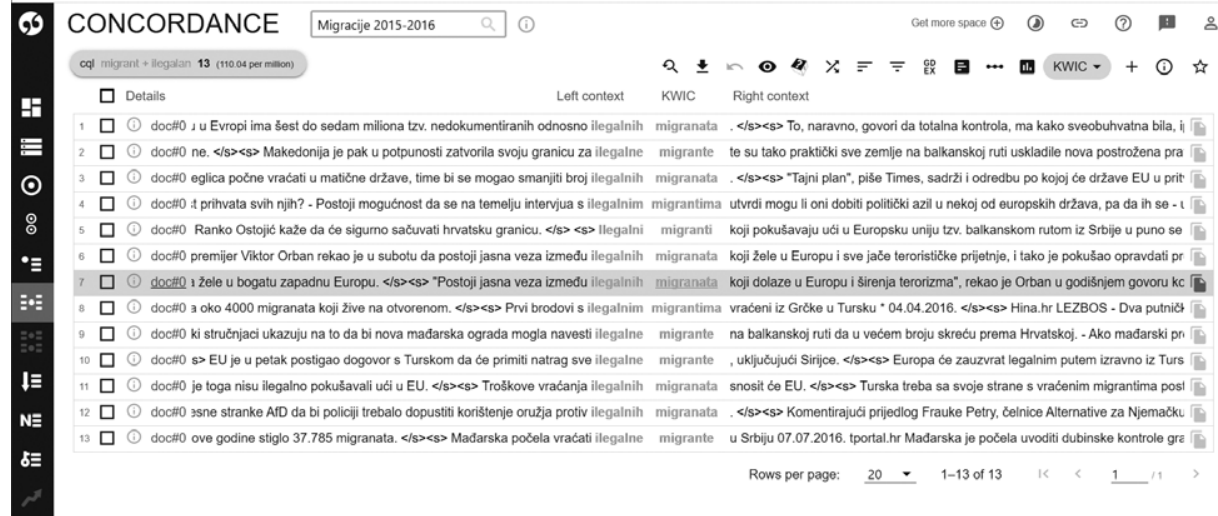

Figure 2. Concordances of collocation ilegalni migrant in MigCorp 2015-2016

Slika 2. Registar riječi po kolokaciji ilegalni imigrant u MigCorpu 2015-2016

ances reported on the Croatian context and the purpose of this paper is to investigate not only Croatian media discourse but also the attitude that Croatian media might impose upon their public with respect to RASIM.

We then created a list of collocate candidates for each RASIM term in each corpus and compared the lists in order to detect both shared and seasonal (Baker et al. 2008) collocational behavior, since one objective of this paper is to investigate the change in the discourse evolving around RASIM.

As indicated in the theoretical background, however, the investigation of discourse is most successful if CL and CDA are combined. Our next step thus included a close analysis of eight texts from each subcorpus, with four published in broadsheets and four in tabloids. Here we analyzed rhetorical devices and strategies (e.g. metaphors which do not necessarily occur as collocates of RASIM) that are used in the media to portray RASIM.

\section{Results of corpus analysis}

Corpus analysis of the key RASIM terms revealed that there are many shared collocates among the terms, but that there are also seasonal ones, typical of only one corpus. These collocates, however, do share some common characteristics, most of which point to the hostile speech against RASIM, even though UNHCR addressed this problem in a report providing practical guidelines by and for journalists on interviewing refugees and asylum seekers and a glossary with appropriate terminology for fair reporting (UNHCR 2016). ${ }^{6}$ 
Migration Discourse in Croatian News Media

\section{Discriminatory collocates}

Corpus data suggest that RASIM terms very often collocate with prepositions prema (towards) and protiv (against). In MigCorp 2002-2014 these prepositions are most frequent with the term azilant, where some concordances of prema suggest that asylum seekers are treated as political issue (e.g. politika/pravila prema azilantima - policy/rules towards asylum seekers) and some that the Croatian public has negative and xenophopic atittudes towards asylum seekers (e.g. netrpeljivost/ekstremni stavovi prema azilantima - intolerance/extreme attitudes towards asylum seekers). In MigCorp 2015-2016, on the other hand, the discriminatory preposition protiv does not occur at all, which might imply a certain degree of improvement regarding the discrimination against asylum seekers. Finally, in MigCorp 20172019 wordsketches of azilant list only prema, which reveals only one occurrence reporting on the German context.

As far as the term migrant is concerned, concordances of preposition prema in MigCorp 2002-2014, although pointing to the objectification of migrants (e.g. politika prema migrantima - policy towards migrants) do reveal occurrences of positive prosody (e.g. promijeniti odnos/stav prema migrantima - to change the relationship/attitude towards migrants). In MigCorp 2015-2016 the term migrant collocates with prema and protiv, with the latter this time associated with the semantic field of "weapon" (e.g. suzavac/oružje protiv migranata - teargas/weapon against migrants), thus adding a degree of violence to the issue of discrimination. This seems to be the case in MigCorp 2017-2019 as well, where it seems that the violence of Croatian police against migrants had deteriorated ${ }^{7}$ (e.g. grub odnos prema migrantima - violent behaviour towards migrants, nezakonita i nasilna politika prema migrantima - illegal and violent policy towards migrants).

The term izbjeglica, on the other hand, is in all three corpora accompanied by both positive and negative connotations (e.g. MigCorp 2002-2014: restriktivna/ zajednička politika prema izbjeglicama - restrictive/common policy towards refugees, dobronamjerni prema izbjeglicama - benevolent towards refugees; MigCorp 2015-2016: predrasude/nasilje/negativni osjećaji prema izbjeglicama-prejudices/ violence/negative feelings towards refugees, politika dobrodošlice/politika otvorenih vrata prema izbjeglicama - welcome policy/policy of open doors towards refugees; MigCorp 2017-2019: ljudsko lice prema izbjeglicama - human face towards refugees, seksualno nasilje prema izbjeglicama - sexual violence against refugees).

Discrimination and political incorrectness are especially visible in the usage of adjectives ilegalni and nezakonit (illegal) as collocates of migrant and imigrant. In MigCorp 2002-2014, for instance, ilegalni (78 occurrences) and nezakonit (2 occurrences) seem to be preferred over the more neutral adjective neregularan (irregular) 
(3 occurrences). Although illegal might be considered as a synonym of irregular in the context of migration, there has been considerable debate about the usage of this adjective, which resulted in the adoption of Resolution 1509 (2006) of the Council of Europe Parliamentary Assembly, in which it is recommended to use the term "irregular migrant" instead of, for instance, "illegal migrant" or "migrant without papers", given the fact that the term irregular is more neutral. ${ }^{8}$ Some of the texts in MigCorp 2002-2014 stem from the period before 2006, but the modifier illegal is used in later texts as well, hence, the usage cannot be completely justified. This seems to hold true for the term imigrant as well, since the collocate ilegalan reveals 25 occurrences, while iregularan does not occur at all. Furthermore, although MigCorp 2015-2016 includes texts from the period after 2006, we still see preference for the collocation ilegalan migrant (13 occurrences) over iregularan ( 8 occurrences) and neregularan migrant (7 occurrences), although the usage of politically correct modifiers has increased. The wider context of the term imigrant in MigCorp 2015-2016 is even more discriminatory, since the modifier ilegalni reveals 16 occurrences, while its more neutral synonym iregularan does not occur at all. Finally, even though the Resolution recommending the usage of irregular migrant was passed as early as in 2006, MigCorp 2017-2019 includes only ilegalan and nezakonit as adjectival collocates of migrant and imigrant.

\section{RASIM as attackers and threat}

Some noun collocates tend to portray RASIM as attackers. For instance, the word meta (target) tends to collocate with azilant in MigCorp 2002-2014. The media reports here that certain countries have traditionally been targets of asylum seekers (index.hr, 2011) and that Switzerland is the most desirable target of asylum seekers (index.hr, 2006). By assigning the connotation of target to the destination countries that asylum seekers choose, the media thus portray asylum seekers as potential attackers. This also seems to be the case with asylum seekers in MigCorp 2015-2017 and their collocate navala (rush on asylum status).

Most recently, in MigCorp 2017-2019, this attack metaphor is evidenced through various verbal collocates involving the semantic prosody of "attack" (e.g. napasti attack, pretuci - beat, ubiti - kill), the wider context of which reports on violence or crimes committed by asylum seekers. One news outlet reports that such incidents are largely covered in the media because perpetrators are foreigners ( $h r t . h r, 2017)$.

Even verbal collocates that are usually positively connotated (e.g. pustiti - release; prihvatiti - accept) tend to involve the semantic prosody of threat and difficulty, for they mostly report on certain countries threatening to release refugees from their borders. 
Some studies suggest that quantifiers are frequent collocates of RASIM in the me$\mathrm{dia}^{9}$, especially those expressing approximate numbers. It seems, however, that MigCorp 2002-2014 does not abound in such loaded quantifiers, but rather only indicates either the exact number or the increase in the number of asylum seekers in general. In later texts, however, we can find approximate quantification with all RASIM terms (e.g. tisuće - thousands, stotina - hundreds, milijuna - millions). While approximate quantification does not directly portray RASIM as threat, portraying them by means of flood metaphors does. A case in point can be found in MigCorp 2002-2014, where the entry of refugees into a country is compared with a river flow (dw.com, 2011).

Similarly, the term imigrant is in the same corpus associated with words from the semantic field of flood (e.g. val imigranata - immigrant wave) and their entry is here compared with the speed and strength of a wave (poslovni.hr, 2011.

Flood metaphors are most frequent in MigCorp 2017-2019 (e.g. dotok azilanatainflow of asylum seekers, val migranata/izbjeglica - wave of migrants/refugees), which might be explained by the fact that Croatia was at that time receiving the highest number of RASIM.

\section{Integration of RASIM}

Integracija (integration) is also a potential collocate, however, its concordances reveal that this is a problem in Croatia and that the policy of integration is non-existent due to the low interest of political elites (index.hr, 2011). This is also confirmed by concordances of the verbal collocate zaposliti (employ), which reveal that nobody wants to hire an asylum seeker (womeninadria, 2013) although the Government has prescribed tax benefits for employers who hire asylum seekers (index.hr, 2011).

In MigCorp 2015-2016, however, collocates of azilant include words that might suggest that the integration of asylum seekers in Croatia has improved. This refers to the collocates integracija and jezik (language), the concordances of which reveal that there are Croatian language courses for asylum seekers, since their integration is very important $(N 1,2015)$.

The wider context of integracija migranata in the same corpus, on the other hand, (4 occurrences with the term migrant) reports on the international and domestic context of migrant integration, where it denotes the semantic prosody of "difficulty" or "impossibility" of integration in both contexts.

Even with the term izbjeglica, where noun collocates include least discrimination (zbrinjavanje - care; smjestaj - accomodation), concordances of integracija reveal that integration is still considered a problem or at least a challenge. As a matter of 
fact, integration seems to have been more difficult to achieve when Hungary built up a wire fence and Slovenia and Croatia could no longer accept such large numbers of people. Verbal collocates of the term migrant in MigCorp 2015-2016 thus include primati (receive), propuštati (admit entry), but also vraćati (return), which might suggests a delay in the reception of migrants. Indeed, the wider context of propuštati reveals a negative prosody, since it reports on Slovenia no longer admitting entry to refugees without proper documentation and returning them to Croatia.

Finally, in MigCorp 2017-2019, the term izbjeglica, although it again includes spašavanje (rescue) and zaštita (protection) as noun collocates, also reveals 12 occurrences of protjerivanje (refoulment), which might resulted from various countries building wire fences and thus leading to the disruption of international cooperation as regards the refugee crisis. The Croatian media and non-governmental organizations are thus here full of criticism towards the Croatian police, accusing them of pushbacks and refoulments.

Word sketches and collocates of the term azilant in MigCorp 2017-2019, however, suggest that the integration of asylum seekers is highest in this period, since the collocates include nouns zapošljavanje (employment) (6 occurrences), osposobljavanje (recruitment) (5 occurrences), suradnja (cooperation) (2 occurrences). Furthermore, for the first time we witness the occurrence of binomial azilant $i$ poslodavac (asylum seeker and employer) (2 occurrences), while in other two subcorpora azilant was coordinated only with terms from the RASIM group, while very often revealing misuse of terminology.

\section{Misuse of terminology}

Even though the terms migrant, refugee and asylum seeker are generally misused in the media, they denote different meanings in international law. UNHCR defines an asylum seeker as "someone whose request for sanctuary has yet to be processed."10 The 1951 Refugee Convention, on the other hand, states that a refugee is "someone who is unable or unwilling to return to their country of origin owing to a well-founded fear of being persecuted for reasons of race, religion, nationality, membership of a particular social group, or political opinion". ${ }^{11}$ Finally, since there was no definition for the term migrant at international level, the International Organization for Migration (IOM) decided to issue a definition for their own purpose. According to IOM a migrant is "any person who is moving or has moved across an international border or within a State away from his/her habitual place of residence, regardless of (1) the person's legal status; (2) whether the movement is voluntary or involuntary; (3) what the causes for the movement are; or (4) what the length of the stay is". ${ }^{12}$ Bearing in mind these definitions, we can claim that in our corpus these terms are sometimes 
used interchangeably. A case in point can be illustrated by the binomial izbjeglice $i$ azilanti (refugees and asylum seekers) in MigCorp 2002-2014, where izbjeglica (refugee) and azilant (asylum seeker) are modified by ekonomski (economic):

U vrlo žučnoj raspravi ministar unutarnjih poslova Ernst Strasser branio je novi zakon ističući da Austrija ne može postati europsko okupljalište svih ekonomskih izbjeglica $i$ azilanata. Prema njegovim riječima, velika većina od 40 tisuća tražitelja azila u Austriji pripada kategoriji "europskih, a ne političkih izbjeglica”. (večernji.hr, 2006)

The definition of the term refugee from the UN Refugee Convention, however, does not leave room for the collocate economic, since a refugee does not flee home due to economic reasons. Given that the above article reports on the words of the Austrian minister Ernst Strasser, it is not clear whether this misuse is also present in the original, or whether it was introduced in this article.

Similarly, in MigCorp 2017-2019 ekonomski izbjeglica (economic refugee) is used interchangeably with ekonomski migrant (economic migrant):

Tzv. migrantska kriza zapravo traje već petnaest godina, a neregularni ekonomski migranti i izbjeglice $i$ ranije su u desetinama tisuća ulazile u Italiju, Španjolsku i Francusku itd., no bombastični naslovi u hrvatskim medijima se pojavljuju tek kad se neregistrirani ekonomski migranti kao i ekonomske i političke izbjeglice pojave u većem broju na hrvatskim granicama na putu prema Njemačkoj. (glas.hr, 2016)

Considering that an economic migrant is "a person who leaves their country of origin purely for economic reasons that are not in any way related to the refugee definition, in order to seek material improvements in their livelihood"13, we can claim that this collocate can only be combined with the term migrant.

In MigCorp 2015-2016 both migrant and imigrant can also form binomials, but only with RASIM categories (e.g. migranti i izbjeglice, imigranti ili tražitelji azila). RASIM terms are again used interchangeably here, , since it is suggested that migrants flee from wars and persecution:

"Europa se suočava s krizom izbjeglica morskim putem koja poprima povijesne razmjere”, upozorava Visoko povjerenstvo UN-a za izbjeglice (UNHCR) ističući da ti migranti i izbjeglice $u$ velikoj većini bježe od ratova, sukoba $i$ progona. (slobodnadalmacija.hr, 2015)

Since refugees are "people who have fled war, violence, conflict or persecution and have crossed an international border to find safety in another country"14, we cannot but conclude that the wider context of the binomial migranti i izbjeglice in the above article leaves the usage of the term migrant unjustified. 
Medij. istraž. (god. 27, br. 1) 2021. (5-27)

\section{Nonsensical collocates}

One of the most frequent adjectival collocates of azilant in MigCorp 2002-2014 is lažni (fake) ( 8 occurrences), which seems to be a colloquial word combination ${ }^{15}$, given that no international legal instrument uses the term fake asylum seekers. The coupling of this colloquialism with the metaphor of flood in the headline Lažni migranti s Balkana zapljusnuli zapadnu Europu (Fake migrants splash Western Europe) (tportal.hr, 2013) constructs asylum seekers as a threat (O’Regan and Riordan 2018).

MigCorp 2015-2016, on the other hand, apart from the collocation lažni azilant (3 occurrences), also includes one "nonsensical" (Baker et al. 2008) word combination. The collocation klimatski azilant (climate asylum seeker), for instance, is a term that does not exist in international law. The UN Refugee Agency does, however, report on the usage of the term climate refugee, but suggests that it was invented by the media. The term is not endorsed by UNHCR. Instead, it is recommended to refer to such persons as the ones "displaced in the context of disasters and climate change". ${ }^{16}$ These two occurrences report on Teitiota $v$ New Zealand case, in which the UN Human Rights Committee, although denying the applicant's claim for refugee status, issued its landmark ruling recognising for the first time that "environmental degradation, climate change and unsustainable development constitute some of the most pressing and serious threats to the ability of present and future generations to enjoy the right to life" ${ }^{17}$ It thus follows that Mr. Teitiota's claim was based on refugee status, given the fact that he fled home due to environmental threats. Therefore, the term klimatski azilant is nonsensical for two reasons, one related to the proper use of terminology (izbjeglica instead of azilant) and the other assigned to the modifier invented by the media, which is non-existent in international law. Interestingly, in MigCorp 2017-2019 we again witness the occurrence of the collocate klimatski, although this time it is combined with izbjeglica. Even though according to the UN Refugee Agency the usage of this collocate might be justified here, , international law does not recognize it.

\section{Results of critical discourse analysis}

As already pointed out elsewhere in this paper, it is not sufficient to resort to CL only to explain why certain collocations occur with high frequencies and some do not. While CL takes into account frequency-based data and the wider context of a collocation, it fails to consider the social, political or historical context of those data. CDA can thus contribute to the complete analysis of migration discourse, since it can identify strategies used by the press with respect to RASIM. Considering that $\mathrm{CDA}$ is time-consuming, we decided to analyse eights texts from each subcorpus 
(four from broadsheets and four from tabloids) to explain the above results of corpus analysis.

It seems that in all three subcorpora the media take the side of RASIM, since they tend to criticize not only the government with respect to its inefficient policy but also the public for its xenophobic attitudes. This comes least to the foreground in MigCorp 2002-2014 since at that time there was not migration crisis. This is also supported by the above corpus data, which reveal that in this corpus there is no approximate quantification and flood collocates are least frequent. The press are nevertheless critical towards the authorities:

Od stupanja na snagu Zakona o azilu u 2004. godini, u Republici Hrvatskoj utočište su zatražile 582 osobe. Odobrena su tri zahtjeva. Nedovoljno i za jednoznamenkasti postotak. (Prezimiti u Beču, jutarnji.hr, 2008)

I Hrvatska se nalazi među 44 zemlje koje su obrađene u ovome izvješću, no mogli bismo reći da ona popravlja europski prosjek zato što je kod nas u 2013. azil zatražilo osam posto manje tražitelja nego godinu prije. (Zemlja smo koju izbjegavaju: Hrvatsku zaobilaze i azilanti, večernji.hr, 2014)

The above extracts are both from broadsheets and we can claim that they both use similar strategies, hence, they do not criticize directly. Jutarnji.hr, for instance, first quotes statistical data and then uses two short sentences (Three applications were approved. Insufficient even for a one-digit percentage), both of which are very effective in directing criticism towards the country regarding the application processing of asylum seekers. Večernji.hr is even less direct in expressing criticism, but by suggesting that Croatia amends the European average, it uses irony to convey the message of the headline itself, hence, that Croatia is a country that even ${ }^{18}$ asylum seekers avoid. Furthermore, although the press never express discrimination against RASIM directly, in this article the conjunction even suggests that asylum seekers are second-class citizens. The press very often reports on the attitudes of local people towards RASIM, revealing that the public does not feel comfortable with living in their vicinity. Here the press suggest that RASIM present a "problem", while again indirectly criticizing the government for not trying to resolve this issue in the last five years:

Problemom stranih izbjeglica u Hrvatskoj bavi se Odjel za strance $i$ azil koji djeluje u sklopu Uprave za upravne i inspekcijske poslove MUP-a. Pitanjem azila i imigracije Vlada će se ove godine morati intenzivno baviti jer se njime nije bavila još od donošenja Migracijske politike Republike Hrvatske za 2007/2008., koju je Sabor usvojio 13. srpnja 2007. ('NISMO RASISTI, ALI NIJE UGODNO. TI LJUDI TUMARAJU BEZ CILJA I GLEDAJU NAŠE CURE' Stanari Dugava nakon tučnjave azilanata, jutarnji.hr, 2013) 
Medij. istraž. (god. 27, br. 1) 2021. (5-27)

Broadsheets, on the other hand, are here more direct with respect to expressing criticism towards Croatian authorities:

Hrvatska politika prema azilantima je sramotna: država smo koja najslabije od najslabijih gleda svisoka i glumi nekakav El Dorado, kao da jučer nismo imali rat $i$ vlastite izbjeglice. Od početka svoga postojanja odobrili smo samo 20 zahtjeva za azil! (Gazi slabe: Primamo 20 puta manje azilanata od EU, net.hr, 2012)

Here the media again report on the small number of approved asylum applications, this time openly criticizing the government for "looking down" on the "weakest of the weakest" and "walking over the weak", as if it hadn't itself experience war and its own refugees. By resorting to figurative expressions and metaphors, the press thus here make criticism even harsher. Nevertheless, RASIM are again objectified, since the press does not suggest that they are treated in an embarrassing manner, but that the policy towards them is embarrassing. In a similar vein, although other articles also tend to portray RASIM as weak or unhappy people who fled war, urging the authorities to help them, by employing the metaphors of flood (e.g. Croatia will also be affected by a migrant wave, poslovni.hr, 2007), they too add a securitisation issue to the portrayal of RASIM.

In MigCorp 2015-2016 criticism is expressed towards both the authorities and other countries, since this is the time when countries began building up fences in order to stop RASIM from entering their territories and the EU raised a discussion on the fair distribution of migrants across EU Member States. The headlines Zapadne zemlje žele nam vratiti 3493 migranta kojima nisu pružile azil (večernji.hr, 2016) and Stižu nam prvi migranti, a nitko ne zna gdje ih smjestiti! Prvi otkrivamo koliko će izbjeglica EU poslati u Hrvatsku (jutarnji.hr, 2015) again dehumanise migrants, portraying them as "things" that Western countries want to "return" to Croatia. Furthermore, by indicating in the headline that they (jutarnji.hr) are the first who will reveal the breaking news, this broadsheet here suggests that the race for being the first in publishing something is more important than the destiny of "objects", which will be "sent" to Croatia. Similarly, večernji.hr criticizes the Croatian public for being irrational regarding those "returned" refugees, while at the same time referring to their distribution and expensive costs which might be incurred upon the country if the rights of asylum seekers are violated:

Nije li apsurdno da zemlja koja ima iskustvo sa stotinama tisuća prognanih $i$ izbjeglih u Domovinskom ratu, ima ikakvih problema s nekoliko stotina ili tisuću stranaca koje bi nam mogli raspodijeliti. (Kršenje prava tražitelja azila državu može skupo koštati, večernji.hr, 2015) 
The article also refers to Croatia's war experience and compares it with the current migration crisis. Croatia, once part of multinational countries (e.g. Austro-Hungarian Empire, Yugoslavia), where a sort of proto-multiculturalism was formed much earlier than in other countries of Western Europe, does have experience in receiving migrants. On the other hand, Croatia was established as a result of homeland war and it was inevitable that an atmosphere of "strong defensive nationalism and strong national identification" (Sekulić, 2003: 155 cited in Čačić Kumpres et al., 2012: 315) will be created. Therefore, a study conducted in 2012 by Čačić Kumpres et al. on the views of Croatian citizens towards migrants suggest that most respondents have an exclusionist attitude towards potential migrants in Croatia owed to the the insufficiency of Croatian post-war policy towards cultural diversity of its society (Čačić Kumpres et al. 2012). While Croatia does have experience in receiving refugees and internationally displaced persons, unlike the situation in the 1990s, the migration flows occurring now have much greater dimensions. By comparison, in 1992 there were 663493 internationally displaced persons and refugees in Croatia, while in 2015 there were days when more than 11 thousand migrants and refugees crossed Croatian border (Esterhajer, 2015 17).

Similarly as in MigCorp 2002-2014, broadsheets are here again more figurative in expressing their attitudes, though this time also more insulting towards RASIM:

Ali nakon dovršetka ograde i zbog sve "nervoznijih" mađarskih vlasti to će im biti manje važno. Jer iz Srbije, žele li se dočepati “obećanih” država Europske unije, poput Njemačke, Austrije, Velike Britanije, skandinavskih zemalja..., osim Mađarske im Hrvatska ostaje jedina opcija. Doduše, i Bugarska i Rumunjska su članice Europske unije, no te im države izgleda ne "mirišu” suviše. (Kad Mađarska završi gradnju zida izbjeglice će krenuti prema Hrvatskoj, express24sata.hr, 2015)

By implying that refugees want to "get hold of" the promised EU Member States and avoid some other countries that "don't have a nice "smell" (literal translation from Croatian where it has a figurative meaning of "being attractive"), refugees are here portrayed as animals and presented as a threat to the security of the country. This threat is sometimes also conveyed in the interviews with politicians, especially those belonging to parties other than the government. In these contexts RASIM are dehumanised or even portrayed as potential terrorists. Furthermore, they are used as a means of promoting one's party program and criticizing the one of the government before the upcoming parliamentary elections:

Među ljudima koji bježe od sigurne smrti i neimaštine zasigurno ima i ubačenih terorista što će se, realno je očekivati, pokazati izuzetno velikim sigurnosnim problemom za cijelu EU, a time i za RH. Stoga Vlada Republike Hrvatske, 
osim logističke pripreme za prihvat izbjeglica, mora osigurati $i$ visoku sigurnosnu pripremljenost za ulazak mogućih terorista. To bi nam bilo daleko lakše da smo se, poput susjedne Slovenije, bolje pripremili i usvojili Plan za izbjeglice te povukli sredstva iz EU za te namjene”, ističe Mirela Holy. (MIRELA HOLY: Među izbjeglicama ima $i$ ubačenih terorista? Kako spriječiti napade?, net.hr, 2015)

Finally, although corpus data from MigCorp 2017-2019 suggest improvement with respect to RASIM integration (e.g. for the first time we witness binomials consisting of constituents other than RASIM), at the same time they also reveal most collocates involving the semantic prosody of "violence". Indeed, results of critical discourse analysis reveal the social and political reasons behind such data. The occurrence of the binomial azilant $i$ poslodavac, for instance, can be explained by the policy of Croatian government to finance the recruitment of asylum seekers and thus support their integration. Such cases are mostly reported in broadsheets, although the numbers of recruited asylum seekers are rather low. While corpus data reveal higher frequency of collocates denoting the semantic prosody of "violence", their wider context reports on incidents committed either by RASIM or local people. Critical discourse analysis, however, reveals the escalation of violence at Croatian borders. It is thus not surprising that in this corpus there is most criticism towards the authorities, especially with respect to the Croatian police, who, as reported by the media (including the foreign ones), started using force against RASIM. While Croatia was at first praised for its migration policy at the beginning of migration crisis, it was later criticized for openly hating migrants (Hrvatska se pretvorila u zemlju koja otvoreno mrzi migrante, index.hr, 2019). Apart from representing RASIM as an issue, this article also approves of the policy of the centre-left government in 2015 and harshly criticizes the current centre-right government, by implying that HDZ is to blame for all negative events in Croatia, including the alleged pushbacks towards Bosnia and Herzegovina, which began after the death of the six-year old Madina from Afghanistan in 2017. Such and similar incidents received considerable coverage in foreign media as well and were condemned by UNHCR, who acknowledged that States have the right to protect their borders, but that "push backs, violence and practices that harm or put lives at risk should stop" and "those seeking asylum must be allowed access to asylum procedures". ${ }^{19}$ This condemnation was followed by Resolution 2299 (2019) of the Parliamentary Assembly of the Council of Europe, who apart from urging member States to refrain from pushbacks, also urge them to "encourage and support legal research, investigative journalism and reliable information from recognised, reputable, international and nongovernmental organisations as a means of correctly informing the public, rather than relying on unsubstantiated reports, hearsay and misinformation". ${ }^{20}$ Otherwise, 
the public is about these incidents informed only through the media, who, as suggested above, sometimes refocus the story to express their own political ideology.

In 2018, another liberal tabloid posed a number of rhetorical questions regarding the reasons why Croatia, itself an immigrant country, cannot accept migrants on its own territory. Although the article addresses Croatian people in general, it is more directed towards Catholics and supporters of HDZ. By quoting the Holy Script and referring to the "love thy neighbour" principle, the article uses irony as a strategic discourse:

Osim toga, sve zabrinute katolike koji ne sumnjaju u svetost Pisma mogao bi, kada su u pitanju stranci u Hrvatskoj, umiriti onaj dio u kojem Gospod zapovijeda Mojsiju da "Ako se stranac nastani u vašoj zemlji, nemojte ga ugnjetavati. Stranac koji s vama boravi neka vam bude kao sunarodnjak; ljubi ga kao sebe samoga."”(Lev, 19,33-34).Ako proučavanje Biblije predstavlja prevelik "zalogaj”, Deklaracija Drugog vatikanskog koncila "Nostra aetate” može se pročitati u par minuta. (BOMBAŠKI NAPADI, OTMICE, UBOJSTVA: Migranti neće $i$ ne smiju postati taoci terorista. I jeste li sigurni o kojim migrantima govorimo?, net.hr, 2018)

The article thus adopts a condescending tone, for it "advises" Catholics on something they should already be familiar with. It continues by suggesting that, should reading the Holy Script be "biting off more than one can chew", Catholics should consult Nostra aetate as the second recommendation on how we should behave towards foreigners. Broadsheets, on the other hand, are again toning down their criticism, but as compared to other subcorpora they are more direct in expressing it in this time period, suggesting that migrants were pushed back towards Bosnia and Herzegovina and Serbia without being offered the possibility of international protection (jutarnji.hr, 2019).

Finally, what also seems to contribute to the discrimination against RASIM is the occurrence of fake news about migrants. While in MigCorp 2002-2014 and MigCorp 2015-2016 the collocation fake news does not occur at all, in MigCorp 20172019 both tabloids and broadsheets report on such instances, admitting that fake news contribute to the creation of xenophobic attitudes among the public. Although the articles we analysed are judgmental about fake news, at the same time they criticize the Croatian authorities for not making the public aware of statistical data reporting on the criminal behaviour of migrants in Croatia, thus again using migrants as a means to an end:

Da su lažne vijesti opasno sredstvo u rukama mrzitelja svega i svačega jer pojačavaju histeriju i ksenofobiju u netolerantnoj zemlji koja još nije naučila čuvati svoje, a poštivati druge i drukčije, svjesna je i policija. Zbog toga MUP 
Medij. istraž. (god. 27, br. 1) 2021. (5-27)

na pojavu lažnih vijesti promptno reagira, demantirajući ih po maksimi da bi istina uvijek trebala biti jača od laži. A da bi ta istina doprla do što većih masa, dobro bi došla i konkretna statistika iz koje bi se moglo vidjeti koliko su kaznenih djela i kojih migranti uistinu počinili te koliki je postotak toga u usporedbi s domicilnim počiniteljima. No tu nastaje problem, jer u MUP-u kažu da oni takvih podataka - nemaju!? (Migranti kao počinitelji kaznenih djela za MUP su statistička pogreška, večernji.hr, 2018)

\section{Conclusion}

Up until recently Croatia used to be an emigration country, but ever since it joined the EU it witnessed significant migrant inflows as did most EU Member States. While Croatia did manage to control migration flows successfully at first, when Hungary built up a wire fence, it was no longer able to accept such large numbers of people on a daily basis. This suggests that "the attempt at control and finding a solution within one nation-state is futile in a situation of lack of solidarity and co-operation between nation-states directly or indirectly implicated in the migration flow" (Čapo, 2015: 389). With this lack of international cooperation came inhuman and degrading treatment, mostly visible in the pushbacks of the Croatian police, which, needless to say, violated the right to asylum and the right to protection against refoulment, both of which stand at the core of international refugee and human rights law. Additionally, the lack of sensitivity for these persons was on one hand also caused by the media, who are often considered to be "ideological brokers" (Bloemmart, 1999: 11). This paper attempts to suggest that RASIM are often discriminated against not only when they are physically pushed back at the borders, but also in the words the media use to report on these incidents. As correctly recognized by UNHCR, "sloppy, unprofessional work on these subjects always hurts the vulnerable in some way". ${ }^{21}$

While it has been shown that discrimination in the media can occur even at phraseological and grammatical level, reasons for that need to be searched in the country's history, culture, cooperation with other countries, political and legal context, but also positioning of the media themselves. Combining CL and CDA seems to be most revealing in this regard. While our corpus data reveal discriminatory collocates, portray RASIM as a threat to national security, involve the semantic prosody of "difficulty" regarding their integration and degrade them by using politically incorrect or nonsensical terms, results of CDA help us reveal the background of this data. Although the Croatian media, both tabloids and broadsheets, mostly criticize the Government (either directly or indirectly) for its inefficient migration policy, they too are responsible for the hostile discourse against RASIM. We can claim that 
migration discourse in Croatian news media is not as discriminatory as in the UK press, but it nevertheless contributes to the creation of xenophobic attitudes among the public. Even though the media do not openly express discrimination, they do so through linguistic means which dehumanize this vulnerable group and portray them as dangerous. Finally, although this discriminatory rhetoric used by the media might sometimes go unnoticed, this study has shown that even a small conjunction like even can have a purposeful aim. We thus have to be mindful of migration discourse, for inhuman treatment does not happen only when there is pushback or refoulment; it occurs also when we make these people subject to political debates or media criticism directed at politicians or authorities. Needless to say, the way migrants, asylum seekers and refugees are portrayed in the media, regardless of the fact whether the view expressed reflects the stance of a political party, a certain politician or the news outlet itself, affects the opinion of the public and contributes to the promotion of discrimination. Being mindful of the language we use when we discuss migration crisis can thus also contribute to raising awareness of the international standards of protection offered to these people. This way, as rightly suggested by Justice Blackmun in Hirsi Jamaa and Others v. Italy, the public would be made aware of the fact that:

"[r]efugees attempting to escape Africa do not claim a right of admission to Europe. They demand only that Europe, the cradle of human rights idealism and the birthplace of the rule of law, cease closing its doors to people in despair who have fled from arbitrariness and brutality. That is a very modest plea, vindicated by the European Convention on Human Rights. We should not close our ears to it".22

\section{ENDNOTES}

1 Migration Data Portal, https://migrationdataportal.org/data?i=inflow_total\&t=2015\&m=1 (8 November 2019).

2 HINA, NEWS-H9176964:1 (17 September 2015).

3 Oxford Dictionaries, https://languages.oup.com/press/news/2019/7/5/WOTY (22 November 2019)

4 The word sketch reveals collocates of a word and represents a one-page summary of the word's grammatical and collocational behaviour. It includes prepositions, verbs, nouns, adjectives, etc. which often occur with the word. https://www.sketchengine.eu/guide/word-sketch-collocationsand-word-combinations/ (6 May 2020).

5 Concordances of a word reveal the wider context of the word. Usually this is a sentence or part of it, but the window can further extended up to the whole parapgraph. https://www.sketchengine.eu/ guide/concordance-a-tool-to-search-a-corpus/ (7 May 2020).

6 Reporting on Refugees. Gudiance by and for Journalists, https://www.unhcr.org/en-ie/58e1ed994. $\operatorname{pdf}(16$ May 2020) 
7 The foreign media have reported repeatedly on the alleged incidents of the Croatian police against migrants (see, for instance, 'Blood on the ground' at Croatia's borders as brutal policing persists, The Guardian, 22 December 2019)

8 Article 7 of the Resolution 1509 (2006) of the Council of Europe Parliamentary Assembly

9 Baket et. al, op.cit (fn 12); Gabrielatos, C., Baker, P., op.cit. (fn 11).

10 United Nations High Commissioner for Refugees (UNHCR) - The UN Refugee Agency, https:// www.unhcr.org/asylum-seekers.html (30 April 2019).

11 UN General Assembly, Convention Relating to the Status of Refugees, 28 July 1951, United Nations, Treaty Series, vol. 189., p. 3.

12 International Organization for Migration, https://www.iom.int/who-is-a-migrant (17 April 2019).

13 Migration and Home Affairs, https://ec.europa.eu/home-affairs/what-we-do/networks/european migration_network/glossary_search/economic-migrant_en. (3 May 2020)

14 United Nations High Commissioner for Refugees (UNHCR) - The UN Refugee, https://www.unhcr.org/what-is-a-refugee.html (30 April 2020).

15 As reported by euractiv, "people who are perfectly aware that they will not be granted asylum but nevertheless take advantage of the assessment period for their applications during which they are provided with free accommodation and some pocket money" are often referred to as "fake asylum seekers", https://www.euractiv.com/section/justice-home-affairs/news/eu-ministers-to-curb-fakeasylum-seekers/825758/ (30 April 2020).

16 Climate change and disaster displacement. https://www.unhcr.org/climate-change-and-disasters. html. (1 May 2020)

17 The UN Human Rights Committee, General comment No. 36 (CCPR/C/GC/36), para. 62.

18 My emphasis.

19 Siegfried, K., The Refugee Brief - 15 July 2019, https://www.unhcr.org/refugeebrief/the-refugeebrief-15-july-2019/ (15 May 2020).

20 Resolution 2299 (2019) of the Council of Europe Parliamentary Assembly, 12.1.5.

${ }_{21}$ Reporting on Refugees. Gudiance by and for Journalists, https://www.unhcr.org/en-ie/58eled994. pdf (16 May 2020)

22 Hirsi Jamaa and Others vs. Italy, Judgment of 23 February 2012, Application no. 27765/09, p. 81.

\section{REFERENCES}

Bagarić, Ž., Mandić, A. (2019) "Istina, mediji i žilet-žica: migranti u hrvatskom medijskom krajoliku", Medias Res, 8 (15), 2423-2443.

Baker, P. et al. (2008) "A Useful Methodological Synergy? Combining Critical Discourse Analysis and Corpus Linguistics to Examine Discourses of Refugees and Asylum Seekers in the UK Press", Discourse and Society, 19 (3), 273-306.

Bloemmart, J. (ed) (1999) Language Ideological Debates, Berlin: de Gruyter: Berlin. Čačić Kumpres, J. et al. (2012) "Migracija, integracija i stavovi prema imigrantima u Hrvatskoj", Revija za sociologiju, 42 (3), 305-336.

Čapo, J, (2015) "The Security-scape and the (In)Visbility of Refugees: Managing Refugee Flow through Croatia", Migracijske i etničke teme, 31 (3), 387-406. 
Esterhajer, J. (2015) "Iskustva zbrinjavanja prognanika i izbjeglica i suvremena izbjegličko-migrantska kriza u Hrvatskoj”, Političke analize, 6 (23), 15-22.

Fairclough, N. (1995) Media Discourse, New York: Bloomsbury Publishing.

Gabrielatos, C., Baker, P. (2008) "Fleeing, Sneaking, Flooding: A Corpus Analysis of Discursive Constructions of Refugees and Asylum Seekers in the UK Press, 1996-2005", Journal of English Linguistics, 36 (5), 5-38.

Georgieu, M., Zaborowski, R., Council of Europe report: Media coverage of "the refugee crisis": A cross-European perspective, DG1(2017)03

Greenslade, R. (2005) Seeking Scapegoats: The Coverage of Asylum in the UK Press, London: Institute for Public Policy Research.

Kilgariff, A. et al. (2014), "The Sketch Engine: ten years on", Lexicography, 1, 7-36.

Lancaster, F. W. (1995) “The evolution of electronic publishing”, Library Trends, 43 (4), 518-527.

Ljubešić, N., Klubička, F. (2014) “ $\{\mathrm{bs}, \mathrm{hr}, \mathrm{sr}\} \mathrm{WaC}$ - Web corpora of Bosnian, Croatian and Serbian", Proceedings of the $9^{\text {th }}$ Web as Corpus Workshop (WaC-9), Goetheburg: Association of Computational Linguistics, 29-35.

O’Regan, V., Riordan, E. (2018) "Comparing the representation of refugees, asylum seekers and migrants in the Irish and UK press: A corpus.based critical discourse analysis", Journal of Language and Politics, 17 (6), 744-768.

Pugh, M. (2004) "Drowning not waving: Boat people and humanitarian at sea", Journal of Refugee Studies, 17, 50-69.

Rasinger, S. (2010) "Lithuanian migrants and crime rocketing: representation of new migrants in regional print media", Media, Culture \& Society, 32 (6), 1021-1030.

Razum, V. (2017) Slika imigranata i imigracijskih procesa u hrvatskim medijima. Migranti u prilozima Jutarnjeg $i$ Večernjeg lista, Zagreb: Sveučilište u Zagrebu (diplomski rad)

Siegfried, K. (2019) The Refugee Brief - 15 July 2019, https://www.unhcr.org/refugeebrief/the-refugee-brief-15-july-2019/ (15 May 2020).

Tzevelekos, V. P., Kastelli Proukaki, E. (2017) "Migrants at Sea: A Duty Of Plural States To Protect (Extraterritorially)?”, Nordic Journal of International Law, 86 (4), 427-269.

Van Dijk, T.A. (2005) Discourse and Racism in Spain and Latin America, Amsterdam: John Benjamins.

\section{Internet sources:}

Climate change and disaster displacement. https://www.unhcr.org/climate-changeand-disasters.html. (1 May 2020) 
Concordance, https://www.sketchengine.eu/guide/concordance-a-tool-to-search-acorpus/ (7 May 2020).

Euractiv, https://www.euractiv.com/section/justice-home-affairs/news/eu-ministers-to-curb-fake-asylum-seekers/825758/ (30 April 2020).

International Organization for Migration, https://www.iom.int/who-is-a-migrant (17 April 2019).

Migration and Home Affairs, https://ec.europa.eu/home-affairs/what-we-do/networks/european_migration_network/glossary_search/economic-migrant_en. (3 May 2020)

Migration Data Portal, https://migrationdataportal.org/data?i=inflow_total\&t= $2015 \& \mathrm{~m}=1$ (8 November 2019).

Oxford Dictionaries. https://languages.oup.com/press/news/2019/7/5/WOTY. (22 November 2019)

Reporting on Refugees. Gudiance by and for Journalists, https://www.unhcr.org/ en-ie/58e1ed994.pdf (16 May 2020)

Article 7 of the Resolution 1509 (2006) of the Council of Europe Parliamentary Assembly

United Nations High Commissioner for Refugees (UNHCR) - The UN Refugee Agency, https://www.unhcr.org/asylum-seekers.html (30 April 2019).

Word sketch. https://www.sketchengine.eu/guide/word-sketch-collocations-andword-combinations/ (6 May 2020).

\section{Legislation and related sources:}

Hirsi Jamaa and Others vs. Italy, Judgment of 23 February 2012, Application no. 27765/09

Resolution 1509 (2006) of the Council of Europe Parliamentary Assembly

Resolution 2299 (2019) of the Council of Europe Parliamentary Assembly

UN General Assembly, Convention Relating to the Status of Refugees, 28 July 1951, United Nations, Treaty Series, vol. 189.

The UN Human Rights Committee, General comment No. 36 (CCPR/C/GC/36) 


\title{
Migracijski diskurs \\ u hrvatskim medijima
}

\author{
Katja Dobrić Basaneže \\ Paulina Ostojić
}

\section{SAŽETAK}

Ovaj se rad bavi migracijskim diskursom u hrvatskim medijima, pri čemu kombinira pristupe korpusne lingvistike i kritičke analize diskursa. Rad se najprije usredotočuje na frazeološki i gramatički kontekst pojmova migrant, imigrant, izbjeglica and azilant, nakon čega istražuje i pozadinu takvog lingvističkog ponašanja. Potonje se istražuje s pomoću kritičke analize diskursa, odnosno analizom izvanjezičnog konteksta. To uključuje analizu povijesnog, kulturološkog i političkog konteksta, a ponekad i relevantne sudske prakse $i$ standarda zaštite zajamčenih u međunarodnom humanitarnom pravu i međunarodnom pravu o ljudskim pravima. Rezultati istraživanja upućuju na činjenicu da se diskriminacija ne događa samo kada je posrijedi nehumano postupanje poput tzv. pushbacks, već i u samom jeziku koji mediji koriste za izvještavanje o procesu migracija.

Ključne riječi: korpusna lingvistika, kritička analiza diskursa, diskriminacija, mediji, migracijska kriza 